\begin{tabular}{|c|l|}
\hline Title & Evolutionary significance of prenuptial molting in female Pagurus hermit crabs \\
\hline Author(s) & Wada, Satoshi; Ito, A tsushi; Mima, Azusa \\
\hline Citation & $\begin{array}{l}\text { Marine Biology, 152(6), 1263-1270 } \\
\text { https://doi.org/10.1007/300227-007-0773-2 }\end{array}$ \\
\hline Issue Date & 2007-11 \\
\hline Doc URL & http://hdl.handle.net/2115/29726 \\
\hline Rights & The original publication is available at www.springerlink.com \\
\hline Type & article (author version) \\
\hline File Information & MB152-6.pdf \\
\hline
\end{tabular}

Instructions for use 


\title{
Evolutionary significance of prenuptial molting in female Pagurus hermit crabs
}

\author{
Satoshi Wada ${ }^{1}$, Atsushi Ito $^{2}$ and Azusa Mima ${ }^{1}$ \\ 1. Laboratory of Marine Biology, Graduate School of Fisheries Science, Hokkaido University \\ 2. Algatech Kyowa, Kyowa Concrete Industry CO., LTD
}

Running head: Prenuptial molt in hermit crabs

Corresponding author: Satoshi Wada

Address: Graduate School of Fisheries Science, Hokkaido University, Minato-cho, Hakodate 041-8611, Japan.

E-mail: wadas@fish.hokudai.ac.jp 
1 ABSTRACT: Molting and breeding entail major energetic costs for female crustaceans.

2 However, females of some hermit crabs perform a molt immediately prior to copulation

3 (prenuptial molt). The evolutionary significance of the prenuptial molt was examined in

4 Pagurus hermit crabs, and two hypotheses were tested; (1) prenuptial molt might enhance

5 the success of the present clutch by cleaning the pleopods of females and thereby preventing

6 eggs from being dislodged from the pleopods, and (2) prenuptial molt might function for

7 growth and increase future fecundity at the cost of energetic expenditure on the present

8 brood. Although these hypotheses are not mutually exclusive, our results rejected the former

9 hypothesis and supported the latter hypothesis. All four Pagurus species examined showed

10 significant negative relationships between prenuptial molting and continuity of breeding;

11 i.e., they showed high molting frequency after they had a long rest period from breeding.

12 Females of P. minutus increased their size through the prenuptial molt, and showed a

13 decreased clutch size due to the molt. The number of dislodged eggs increased if females

14 molted in P. minutus. These results suggest that hermit crabs undergoing a prenuptial molt

15 might not gain any clear immediate advantage of enhanced survival of eggs in the present

16 clutch, and that the prenuptial molt would mainly contribute to growth. 


\section{INTRODUCTION}

The allocation of resources to competing phenotypic traits is the central assumption of life history theory. An increase in one life history trait that by itself increases fitness, such as an increase in fecundity, is often countered by a change in another trait that decreases fitness (Roff, 1992; Stearns, 1992). Particularly, a trade-off between growth and reproduction exists in unicellular and multicellular organisms and can be regarded as universal characteristic of life (Cavalier-Smith, 1980; Stearns, 1992). The allocation of resources to growth typically decreases present fecundity although it increases future fecundity in many organisms in which fecundity increases with body size. Animals with indeterminate growth like many crustaceans, gastropods and other invertebrates face this trade-off over their lives.

\section{Prenuptial molt in crustaceans}

Molting and breeding entail major energetic costs for female crustaceans.

Nevertheless, females of some crustaceans go through a molt as a part of a series of reproductive activities. Mating may occur either in recently molted (soft shelled) females or in inter-molt (hard shelled) females in crustaceans. Prenuptial molt is defined as molt of female occurring immediately prior to copulation. Crustacean biologists have paid much attention to the prenuptial molt. Hazlett $(1969,1972)$ reported that the duration of copulation is shorter for molted females than for those without the prenuptial molt in hermit crabs. Brockerhoff and McLay (2005) have experimentally demonstrated that environmental factors affect the receptive period of females after molting in a rock crab. Some brachyurans are considered to be able to breed only after prenuptial molting while other species have the proximate mechanisms enabling mating without prenuptial molting (Hartnoll 1969; Henmi \& Murai 1999). Hartnoll (1985, 2000) has reviewed the patterns 
1 between reproduction and molt among various crustacean taxa, and has discussed about

2 why females conduct prenuptial molt in some crustaceans. However, there is no study

3 directly examining the evolutionary significance of the prenuptial molt.

Variation in the occurrence of the prenuptial molt in Pagurus hermit crabs provides a good opportunity for studying the evolutionary significance of the prenuptial molt. Unlike brachyurans, males of hermit crabs lack intromittent organs for transferring the spermatophores into the female genital tract (Subramoniam 1993). The spermatophores are attached to the external carapace of female (e.g., Tudge 1991), and ovulation occurs only after the spermatophore deposition (Subramoniam 1993). Therefore, copulation must precede every clutch production in hermit crabs (e.g., Hazlett 1996). If they can not copulate and extrude eggs without a prenuptial molt, females of hermit crabs should always molt before breeding (i.e., copulating and extruding eggs). Females of P. marshi Benedict (Hazlett 1975) and P. nigrofascia Komai (S. Wada, unpublished) always molt before copulating and subsequent ovulation (hereafter referred to as molt species). However, females of $P$. anachoretus (Risso) (Hazlett 1975) and P. middendorffii Brandt (Wada et al. 1995; Wada 2000) do not molt before copulation (hereafter referred to as no-molt species), and many other species, including P. pygmaeus (Bouvier), P. miamensis Provenzano (Hazlett 1975), P. filholi De Man, $P$. nigrivittatus Komai, $P$. minutus and P. lanuginosus De Haan (this study), sometimes molt before breeding (hereafter referred to as intermediate species) (Hazlett 1975; Wada 2000). We focus here on four intermediate species (P. filholi, P. nigrivittatus, $P$. minutus and P. lanuginosus) to examine the adaptive significance of the prenuptial molt.

Hypotheses for prenuptial molt

Two hypotheses are proposed to explain the relationship between the prenuptial molt and reproduction in hermit crabs. First, females may molt just before ovulation to 
1 conduct the renewal of the surface on their pleopods, reducing the incidence of egg loss

2 from the plepods and consequently increasing success of brooding the current clutch.

3 Females molt, copulate and ovulate within a day in P. filholi, P. nigrivittatus and P. minutus,

4 and within two days in P. lanuginosus (S. Wada, unpublished). Hermit crabs use the

5 pleopods for attaching their eggs. After hatching of the brood, any dead eggs, empty egg

6 capsules and particles of egg membrane remain on the pleopods for a period (Wada et al.

7 2000a). We then hypothesize that the remnants of egg capsules may prevent subsequent

8 eggs from attaching to the pleopods. The intermediate species, P. filholi, P. nigrivittatus, $P$.

9 minutus and P. lanuginosus, have more than one clutch during their reproductive seasons

10 (Goshima et al. 1998; Wada et al. 2000a, 2005), while a molt species, P. nigrofascia

11 (Goshima et al. 1996) and a no-molt species, P. middendorffii (Wada et al. 1995, 1999),

12 have an annual clutch. If the prenuptial molt functions for cleaning the pleopods, females of

13 these intermediate species should molt when they successively produce clutches (hereafter

14 referred to as continuous breeding), whereas it would not be necessary to molt when they

15 have a sufficient rest period between the serial clutches to clean their pleopods (hereafter

16 referred to as discontinuous breeding). Although there may be an energetic cost for the

17 prenuptial molt, females might decrease their clutch size to reduce the alternative fitness

18 cost of dislodging eggs from pleopods. In the cleaning hypothesis, we expect a positive

19 correlation between molt and continuity of breeding in the intermediate species with

20 multiple clutches per year (Fig. 1a).

21 The growth hypothesis expects that the prenuptial molt functions for increasing the

22 body size. Since the clutch size typically increases with the female body size (Wada et al.

23 1995, 2000), the prenuptial molt might increase the future reproductive success in the same

24 way as a normal molt. The cleaning and growth hypotheses are not mutually exclusive, and

25 the prenuptial molt could have both functions of cleaning and growth. However, if females

26 with a prenuptial molt have a longer interval between spawning of successive clutches 
1 because of the energetic costs of the molt than those without a prenuptial molt, females

2 might tend to molt when they have a reproductive rest period between adjacent clutches

3 (discontinuous breeding) (Fig. 1b). In this case, the cleaning and growth hypotheses would

4 be distinguishable from each other in a phenotypic trade-off between the prenuptial molt

5 and continuity of breeding. Furthermore, if the energetic costs of molt and reproduction are

6 relatively low for females, females could increase both the present and future reproduction

7 by the prenuptial molt. In this case, the frequency of prenuptial molts will be related to other

8 factors, such as temperature, and will not be related with the continuity of breeding (Fig. 1c, 9 d).

Size of the hermit crab's shelter (i.e., gastropod shell) may be a factor in determining the allocation between growth and reproduction (Bertness 1981; Hazlett et al.

12 2005). Bertness (1981) reports for tropical hermit crabs, Clibanarius albidigitus, Calcinus

13 obscurus and Pagurus sp., that small sized gastropod shells occupied by females impedes

14 growth and results in the females allocating more time and energy to reproduction. Crabs with a relatively poor supply of shells reproduce at smaller sizes, reproduce more frequently, have larger clutches, and are unable to grow to larger sizes than crabs with a less limited shell supply. In the growth hypothesis, intermediate species may have flexibility in life history traits, and the prenuptial molt may be conducted at the expense of the present reproductive rate when females occupy shells large enough to allow growth.

Aims of this study

We test here the above hypotheses in Pagurus hermit crabs. We ask the following questions: (1) Does the prenuptial molt mainly occur with continuous or with discontinuous breeding? (2) Does the prenuptial molt increase the body size of the female? (3) Is occurrence of a prenuptial molt correlated with shell size, the present clutch size and the 


\section{MATERIALS AND METHODS}

number of eggs dislodged from pleopods? left chela, over a period of several days.

Females of $P$. filholi, $P$. nigrivittatus and $P$. minutus produce several clutches mainly from October to April in Tosa Bay, Shikoku, Japan $\left(33^{\circ} \mathrm{N}, 133^{\circ} \mathrm{E}\right)$ (Wada et al., 2005). In Hakodate Bay, Hokkaido, Japan $\left(41^{\circ} \mathrm{N}, 140^{\circ} \mathrm{E}\right)$ females of P. filholi and $P$. lanuginosus produce more than one clutch from March to July (Goshima et al. 1998) and from February to June (Wada et al. 2000), respectively. In the reproductive seasons males of all species show the precopulatory guarding behavior typical of Pagurus species (Hazlett 1972) in which they grasp the aperture of the shell occupied by a mature female with their

To examine the relationship between the prenuptial molt and continuity of breeding, we collected guarding pairs of Pagurus during low tides in the peak of their reproductive seasons from 2003-2006 (Table 1), i.e., when each population had the highest frequency of ovigerous females (Wada et al. 2000, 2005). Each pair was placed in a vinyl pouch in the field and brought back to the laboratory. First, we turned over the female, waited for that the female tried to right herself, and then observed the female's pleopods using a stereoscopic microscope in order to check for clean pleopod setae, and for developing eggs or remnant egg capsules. Thus, we defined the females of continuous and discontinuous breeding as follows: females in precopulatory mate guarding with old eggs or remnants of capsules on their pleopods were designated "continuous breeding", and those with clean pleopods as "discontinuous breeding". Each pair was kept in a small container $(14 \times 9 \times 7 \mathrm{~cm}$ height $)$ or in a polystyrene cylinder $(200 \mathrm{ml})$ in the laboratory for a week or until the female bred. When a female did not breed during the one week period, we returned the pair to the sea. We checked every day whether the females had molted or not. Since the 
1 females extrude their eggs and attach them to their pleopods within an hour after copulation

2 (Hazlett 1966; S. Wada, personal observation), we observed the pleopods of females every

3 day under a stereoscopic microscope to determine whether the females had bred or not.

4 Pairs were not fed during the rearing period and the seawater was exchanged every two

5 days.

Samples of $P$. minutus collected in January and February 2004 were further used to examine the relationship between the prenuptial molt and some quantitative traits. After the females bred, we counted the number of eggs on the bottom of the container, which failed to attach to their pleopods, and measured the shell width of the gastropod shell that the female occupied. Then we fixed the females in $5 \%$ seawater formalin, counted the number of eggs attached to their pleopods and measured the shield length (calcified anterior portion of the cephalothorax; hereafter, SL) under a stereoscopic microscope. When the females molted, the SLs of ecdysis were also measured. Five of 104 females were excluded from the following statistical analysis because the eggs on their pleopods were firmly stuck together and it was not possible to count the number of eggs.

Since molt and continuous breeding females have higher energetic requirements than no-molt and discontinuous breeding females, we dealt with the data of these categories as binary rank data (i.e. no-molt $=0$, molt $=1$; discontinuous $=0$, continuous $=1$ ). The rank data of the four Pagurus species were tested with nonparametric Kendall's rank correlation test to examine whether they have a positive or negative correlation between the prenuptial molt and continuity of reproduction. In the molting females of P. minutus collected in January and February 2004, we used a one-sample t-test for growth increment (difference between SL of pre- and post-molt female) to determine whether the prenuptial molt contributes to growth. Logistic regression analysis was carried out to investigate whether the binary variable of molt (no-molt $=0$ vs. molt $=1$ ) was related to clutch size, the number of dislodged eggs, female size and shell size. SLs of exoskeltons were used for female size 
1 in the molting females, if available. Since both clutch size and shell size were highly

2 correlated with female size, we calculated their residuals from the least squares regressions

3 between each variable and female SL, and used the residuals as variables in the logistic

4 regression analysis.

5

6

7

\section{RESULTS}

Table 1 shows the results of the number of molt females with continuous or discontinuous breeding, and we found that females of the four Pagurus species showed significant negative relationships between prenuptial molting and continuity of breeding; i.e., they showed high molting frequency after they had a long rest period from breeding (discontinuous breeding) in all cases (Kendall's rank correlation test, $\mathrm{n} \geq 60, \tau \leq-0.097, \mathrm{p}<$ 0.05). We observed in eight samples of $P$. filholi in 2006 that empty egg capsules were attached to abdominal ecdysis after molting in eight samples, meaning that the prenuptial molt cleaned the pleopods in females with continuous breeding. However, we also found in the 2006 samples of P. filholi and P. lanuginosus that, when females continuously bred clutches without molting, empty egg capsules with the tip of female pleopods were shed just after hatching of the previous clutch ( 6 and 4 samples, respectively), although we were not able to examine whether the females actively removed the egg debris from their pleopods or not.

Logistic regression analysis of the P. minutus data showed the significant correlation between breeding continuity on the prenuptial molt (Table 2 and Fig. 2). The occurrence of the prenuptial molt significantly decreased clutch size (Fig. 3), and significantly increased the number of dislodged eggs (Fig. 4). However, there was no significant effect of female size and relative shell size upon the occurrence of the prenuptial molt (Table 2). 
Although we observed 42 molts in P. minutus, for 12 exoskeletons we were not

2 able to measure SL of exoskeleton because the crabs ate and/or crushed the shield of

3 carapace of the exoskeleton. We observed one case for continuous breeding with a zero

4 increment and two cases for discontinuous breeding with minus increments. However,

5 growth increments of most females that molted, irrespective of the continuity of breeding,

6 were plus values (one-sample t-test, $\mathrm{n}=30, t=3.83, \mathrm{p}<0.001$ ), indicating that prenuptial

7 molt contributed to growth. There was no significant difference between the increments of

8 females with continuous breeding and those with discontinuous breeding (Mann-Whitney

$9 U$-test, $U=104.5, \mathrm{p}=0.771$ ), and no significant correlation between female SL and growth

10 increment (linear regression analysis, $F_{1,28}=0.037, \mathrm{p}=0.849$ ) (Fig. 5).

\section{DISCUSSION}

Our data are consistent with the growth hypothesis but cause us to reject the cleaning hypothesis. Females tended to molt with discontinuous breeding in all study populations, and grew larger after the prenuptial molt in P. minutus. Even when a female continuously bred without molting in P. filholi and P. lanuginosus, the empty egg capsules were shed from the pleopods of the female after hatching of the last clutch. Anomurans, including hermit crabs, are generally considered to clean their pleopods by the fifth pereopods (Bauer 1981; Martin and Felgenhauer 1986), and all species in this study have well-developed fifth pereopods. The prenuptial molt would not be necessary for females to clean their pleopods in our species. Molting decreased the clutch size of the ensuing brood and actually increased the number of dislodged eggs from the pleopods of females.

24 Although some cases of zero and minus growth were observed in P. minutus in this study, a 25 similar growth pattern during the non-reproductive season was reported in other hermit crabs (Asakura 1992; Wada 2000). Prenuptial molting with zero or minus growth may allow 
1 the regeneration of parts of the body or in cleaning the exoskeletal parts, such as mandibles,

2 chelae and gastric mill. These results suggest that the prenuptial molt would decrease

3 brooding success for the next clutch, although it might increase future reproductive success

4 through growth increment of the body size. Therefore, the evolutionary significance of

5 prenuptial molt is concluded not to differ from that of a normal molt.

Our results may underestimate the molting frequencies in the cases of

7 discontinuous breeding. The definition of discontinuous breeding in this study was not able

8 to exclude possible misidentification. Firstly, we might misidentify females that had already

9 molted as those of discontinuous breeding. Secondly, females are able to clean their

pleopods without molting even when they perform continuous breeding. When we collected

11 females showing continuous breeding after they molted or cleaned their pleopods, we might

12 have misidentified them as females of discontinuous breeding. Molting frequency of such

13 individuals should decrease the molt frequency of females identified as discontinuous

14 breeding. Nevertheless, all populations showed negative phenotypic correlations between

the prenuptial molt and the breeding continuity, implying that females face an energetic trade-off between growth and reproduction.

Although perennial species with indeterminate growth, like hermit crabs, must

allocate time and energy to growth and reproduction after maturation, the allocation pattern typically depends on the body size. Theoretical studies have often predicted that allocation to growth in such species will decrease with increasing body size, which leads to S-shaped growth curves (e.g. Kozłowski \& Uchmanski 1987). On the other hand, the size of gastropod shell that a female occupies might also influence the allocation to growth and reproduction in hermit crabs (Bertness 1981; Hazlett et al. 2005). In the tropical hermit crab,

24 Clibanarius albidigitus, females with shells large enough to allow growth tend to put effort 25 into growth at the expense of immediate reproductive expenditures, while crabs in shells too small to permit growth allocate increased energetic expenditure into present reproductive 
1 gains (Bertness 1981). However, we did not find any significant effects of female body size

2 and shell size on the frequency of prenuptial molt in P. minutus. Several possibilities could

3 be considered to explain the results. First, since the size range of female P. minutus was

4 relatively small compared to the other species (Wada et al. 2005), the sample size might be

5 insufficient to detect the effect of body size on the frequency of prenuptial molt.

6 Interspecific variation in the prenuptial molt frequency in our results seems to show a

7 size-dependent depression in the allocation to growth. The lowest frequency of molting of

8 this study was observed in P. lanuginosus, which females have been reported to mature at

9 the largest size of the species examined in this study (Wada et al. 2000a, 2005). Second, the

10 female size and the shell size may also relate to the number of clutches per reproductive

11 period. Timing to start breeding in a reproductive season differs with female size in some

12 hermit crabs (Wada et al. 1996; Wada 2001; Yoshino et al. 2002). Large females start

13 breeding earlier in the reproductive season than small ones in P. middendorffii (Wada et al.

14 1996) and P. filholi (Yoshino et al. 2002). Large females might allocate more time to reproduction than small ones, although energy allocation did not vary with body size in $P$. minutus during our study period. Finally, tropical hermit crabs show a higher ovigerous frequency under limited shell availability than under unlimited conditions (Bertness 1981).

18 Limitation in shell availability is usually more severe for large individuals than for small

19 ones (Ohmori et al. 1995; Wada 1999; Yoshino et al. 2001). Small females of P. minutus

20 that occupy large shells to permit growth might tend to perform a normal molt, without

21 breeding, even during the reproductive season. Consequently, shell condition might not vary

22 with female size among breeding females. Experimental studies are needed to examine 23 these possibilities.

24 Pagurus hermit crabs include species in which females either always molt or

25 females do not molt just before breeding. Interspecific variation in growth and reproductive 26 phenologies of Pagurus species may explain the reasons why some species have a 
1 deterministic pattern and why other species may or may not perform a prenuptial molt prior

2 to reproduction. Females of the no-molt species, P. middendorffii in Hakodate Bay, have a

3 higher molt frequency and increment rate per molt from spring to summer than from

4 autumn to winter (Wada 2000), whereas females of this species have a clutch in winter,

5 from November to the next February (Wada et al. 1995). The ovigerous season of $P$.

6 middendorffii does not overlap with their growth season, and the females do not molt just

7 before breeding. On the other hand, although the molt species, P. nigrofascia in Hakodate

8 Bay, also has an annual clutch, females breed from April to May and continue to be

9 ovigerous until the next February (Goshima et al. 1996). Their long ovigerous season might overlap broadly with their growth season. Other intermediate species in Hakodate Bay, such

11 as P. filholi (Goshima et al. 1998), P. lanuginosus (Wada et al. 2000a) and P. proximus

12 Komai (Wada \& Mima, 2003), have more than one clutch from spring to summer. We

13 suggest that the overlap between the growth and reproductive seasons might be an important factor influencing the frequency of a prenuptial molt in hermit crabs.

In conclusion, this study found that the prenuptial molt does not increase the reproductive success of the current brood, but will result in growth and increase future fecundity. The relationship between the prenuptial molt and reproduction should be treated as a simultaneous phenotypic trade-off between growth and reproduction. However, some questions remain, such as what factors affect the frequency of a prenuptial molt and why the timing of the molt is just before reproduction, even when the females have a rest period between two ovigerous periods. Further field and laboratory investigations are needed to detail factors affecting reproduction in these species.

Acknowledgements. We thank all members of the Benthos Group of Laboratory of Marine Biology, Hokkaido University. We are grateful to Dr. S. Goshima, Dr. T. Oba, Dr. C. Norman and two anonymous reviewers for their invaluable comments on the manuscript. 
1 This work was supported by a Grant-in-Aid for Scientific Research (no. 15770010 and

2 17770018) to S. Wada from the Ministry of Education, Culture, Sports, Science and

3 Technology of Japan. The experiments reported herein comply with the current laws of 4 Japan.

5

\section{REFERENCES} 12:537-545 Biol 1:153-173 13:151-162

Asakura A (1992) Population ecology of the sand-dwelling hermit crab Diogenes nitidimanus Terao. 5. Ecological implications in the pattern of molting. J Crust Biol

Bauer RT (1981) Grooming behavior and morphology in the decapod Crustacea. J Crust

Bertness MD (1981) Pattern and plasticity in tropical hermit crab growth and reproduction. Am Nat 117:754-773

Brockerhoff AM, McLay CL (2005) Factors influencing the onset and duration of receptivity of female purple rock crabs, Hemigrapsus sexdentatus (H. Milne Edwards, 1837) (Brachyura: Grapsidae). J Exp Mar Biol Ecol 314:123-135

Cavalier-Smith T (1980) R- and K-tactics in the evolution of protist developmental systems: cell and genome size, phenotypic diversifying selection, and cell cycle patterns. Biosystems 12:43-59

Goshima S, Wada S, Ohmori H (1996) Reproductive biology of the hermit crab Pagurus nigrofascia (Anomura: Paguridae). Crust Res 25:86-92

Goshima S, Kawashima T, Wada S (1998) Mate choice by males of the hermit crab Pagurus filholi: Do males assess ripeness and/or fecundity of females? Ecol Res

Hartnoll RG. (1969) Mating in the Brachyura. Crustaceana 16:161-181

Hartnoll RG (1985) Growth, sexual maturity and reproductive output. In: Wenner AM (ed) 
Hartnoll RG (2000) Evolution of brachyuran mating behavior: relation to the female molting pattern. In: Klein V, Carel VJ (eds) Crustacean issues 12: The biodiversity crisis and Crustacea. New York: A. A. Balkema, p 519-525

Hazlett BA (1968) Sexual behavior of some European hermit crabs (Anomura: Paguridae). Pubbl Staz Zool Napoli 36:238-252

Hazlett BA (1972) Shell fighting and sexual behavior in the hermit crab genera Paguristes and Calcinus, with comments on Pagurus. Bull Mar Sci 22:806-823

Hazlett BA (1975) Ethological analyses of reproductive behavior in marine Crustacea. Pubbl Staz zool Napoli 39:677-695

Hazlett BA (1996) Reproductive behavior of the hermit crab Clibanarius vittatus (Bosc, 1802). Bull Mar Sci 58:668-674

Hazlett, B.A., Rittschof, D., and Bach C.E (2005) The effects of shell size and coil orientation on reproduction in female hermit crabs, Clibanarius vittatus. J Exp Mar

Henmi Y, Murai M (1999) Decalcification of vulvar operculum and mating in the ocypodid crab Ilyoplax pusilla. J Zool 247:133-137

Kozłowski J, Uchmanski J (1987) Optimal individual growth and reproduction in perennial

Ohmori H, Wada S, Goshima S, Nakao S (1995) Effects of body size and shell availability on the shell utilization pattern of the hermit crab Pagurus filholi (Anomura:

Roff DA (1992) The Evolution of Life Histories: Theory and Analysis. Chapman and Hall, 
Subramoniam T (1993) Spermatophores and sperm transfer in marine crustaceans. Adv Mar Biol 29:129-214

Stearns SC (1992) The Evolution of Life Histories. Oxford University Press, New York

Tudge CC (1991) Spermatophore diversity within and among the hermit crab families, Coenobitidae, Diogenidae, and Paguridae (Paguroidea, Anomura, Decapoda). Biol Bull 181:238-247

Wada S (1999) Environmental factors affecting sexual size dimorphism in the hermit crab Pagurus middendorffii. J Mar Biol Assoc UK 79:953-954

Wada S (2000) Seasonal growth pattern and the effect of gastropod shells on sexual growth rates in the hermit crab Pagurus middendorffii. Bull Fac Fish Hokkaido Univ 51:1-11

Wada S (2001) Reproductive characters and population structure of the subtidal hermit crab Pagurus ochotensis. Benthos Res 56:43-46

Wada S, Goshima S, Nakao S (1995) Reproductive biology of the hermit crab Pagurus middendorffii Brandt (Decapoda: Anomura: Paguridae). Crust Res 24:23-32

Wada S, Sonoda T, Goshima S (1996) Temporal size covariation of mating pairs of the

Wada S, Ashidate M, Goshima S (1997) Observations on the reproductive behavior of the spiny king crab Paralithodes brevipes (Anomura: Lithodidae). Crust Res 26:56-61

Wada S, Tanaka K, Goshima S (1999) Precopulatory mate guarding in the hermit crab Pagurus middendorffii (Brandt) (Decapoda: Paguridae): effects of population

Wada S, Kitaoka H, Goshima S (2000) Reproductive traits of the hermit crab Pagurus lanuginosus and comparison of reproductive traits among sympatric hermit crabs. $\mathbf{J}$ Crust Biol 20:474-478 
1 Wada S, Mima A (2003) Reproductive characters of the hermit crab Pagurus proximus Komai 2000 in Hakodate Bay, southern Hokkaido, Japan. Crust Res 32:73-78

3 Wada S, Mima A, Ito A (2005) Reproductive phenology of sympatric hermit crabs in 4 temperate Japan. J Mar Biol Assoc UK 85:889-894

5 Yoshino K, Goshima S, Nakao S (2001) Sexual difference in shell use in the hermit crab 6 Pagurus filholi (De Man) from northern Japan. Crust Res 30:55-64

7 Yoshino K, Goshima S, Nakao S (2002) Temporal reproductive patterns within a breeding 8 season of the hermit crab Pagurus filholi: effects of crab size and shell species. Mar 9 Biol 141:1069-1075 


\section{Figure Captions}

Fig. 1. Bubble charts showing predictions of three hypotheses for allocation between the prenuptial molt and continuity of breeding. If the prenuptial molt functions for cleaning female pleopods, the females should molt when they breed two successive clutches without a rest period and there should be a positive correlation between molt and continuity of breeding (a). If the prenuptial molt functions for growth, energetic trade-off between the prenuptial molt and continuity of breeding might be found (b). If any other factors determine the frequency of the prenuptial molt irrespective of the continuity of breeding, there should be no correlation between them (c, d). The bubble size represents the frequency of cases in each category.

Fig. 2. Frequencies (\%) of molt/no-molt in two cases that females perform continuous or discontinuous breeding in Pagurus minutus. The number in each bubble represents the molt or no-molt percentage in continuous or discontinuous breeding, and the numbers in parentheses represent the number of females in each case.

Fig. 3. Relationship between clutch size and female size in Pagurus minutus.

Fig. 4. Differences of mean number of eggs dislodged from female's pleopods just after extrusion of the clutch in Pagurus minutus. Four categories (C-M, C-nM, D-M and D-nM) indicate the female conditions as follows, respectively; molt in continuous breeding, no-molt in continuous breeding, molt in discontinuous breeding and no-molt in discontinuous breeding. Error bars represent standard deviations of the estimates.

Fig. 5. Relationship between growth increment and female size in Pagurus minutus. Dashed line represents zero growth increment. 

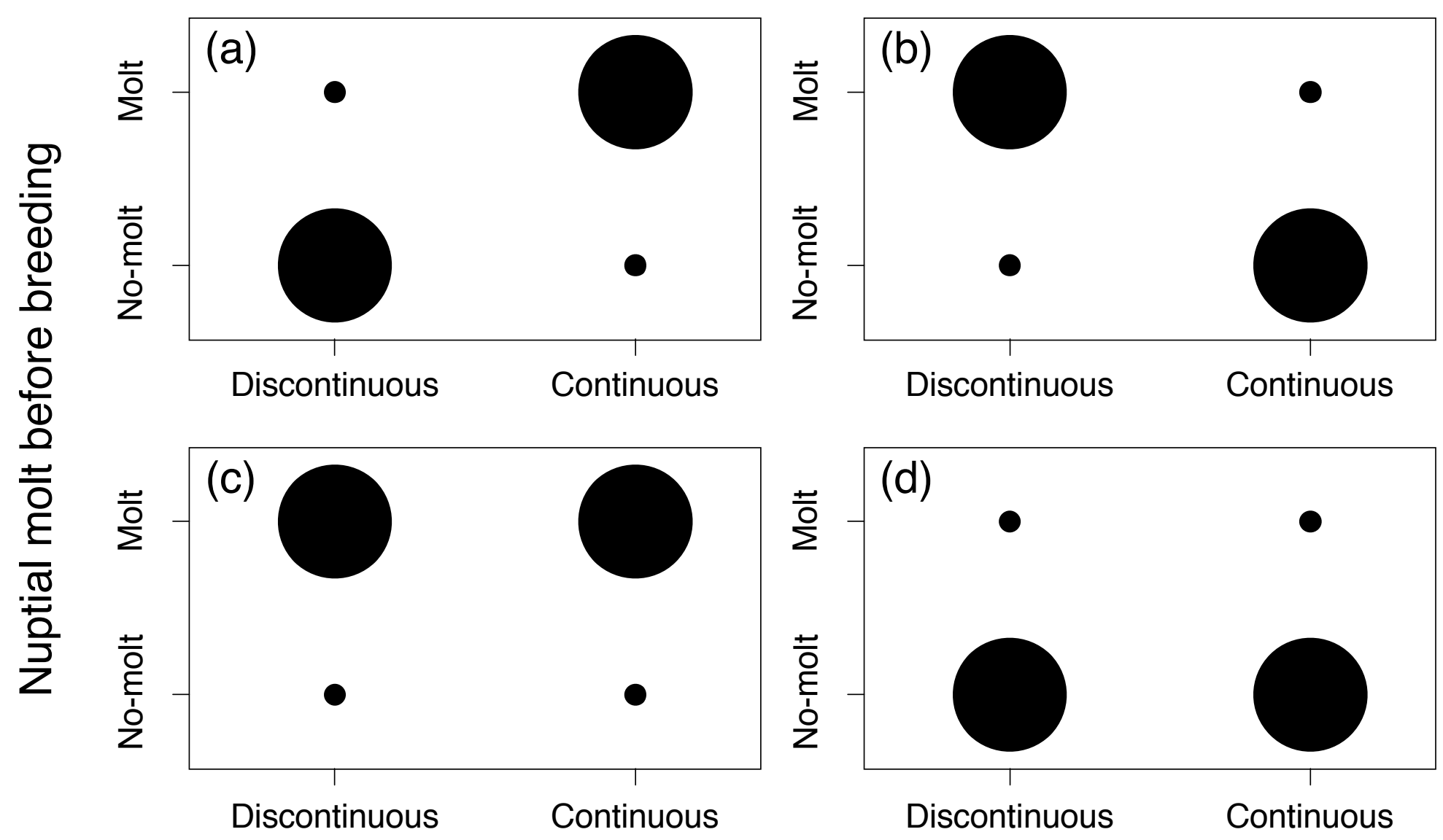

Continuity of breeding

Fig. I 


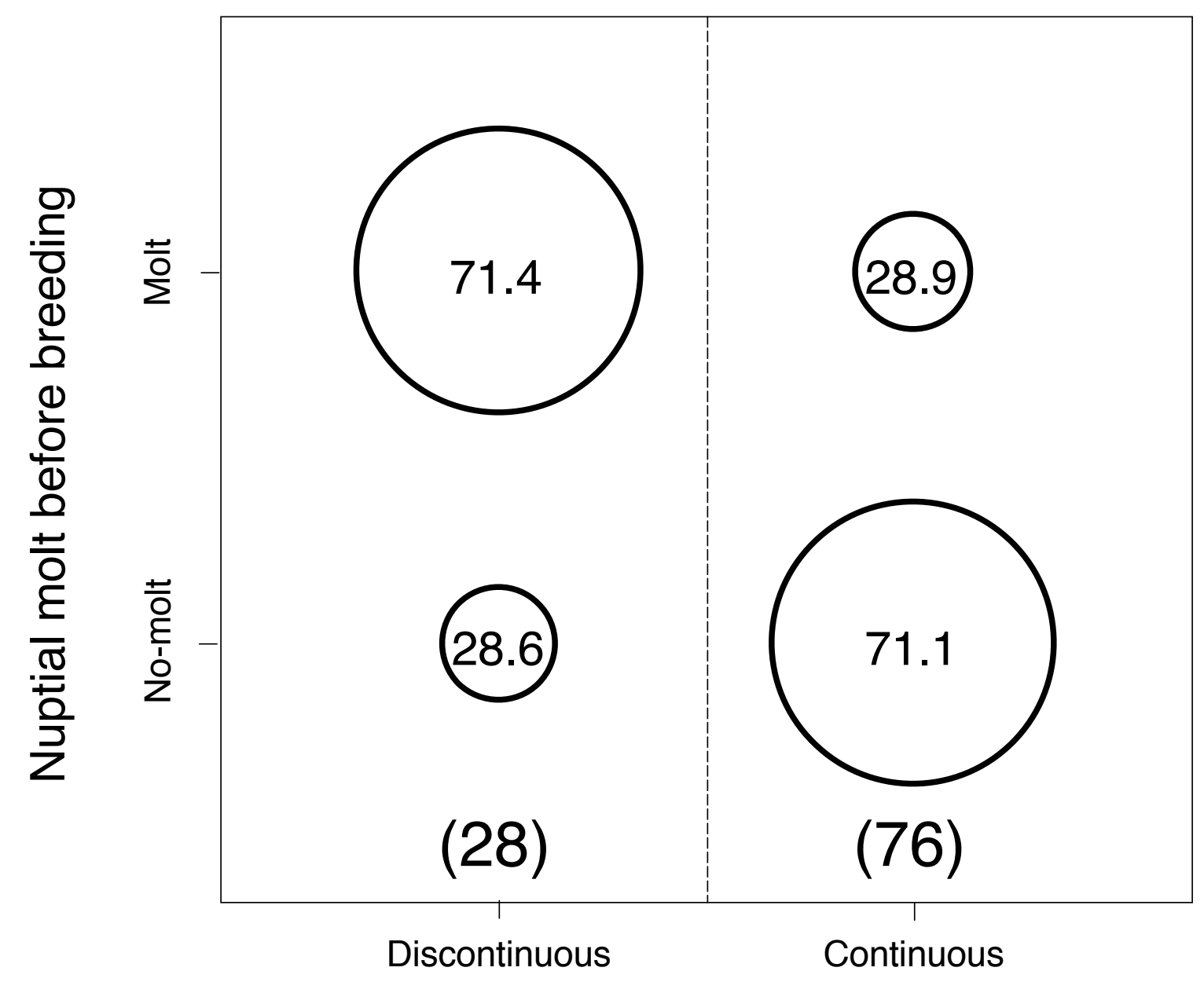

Continuity of breeding

Fig. 2 


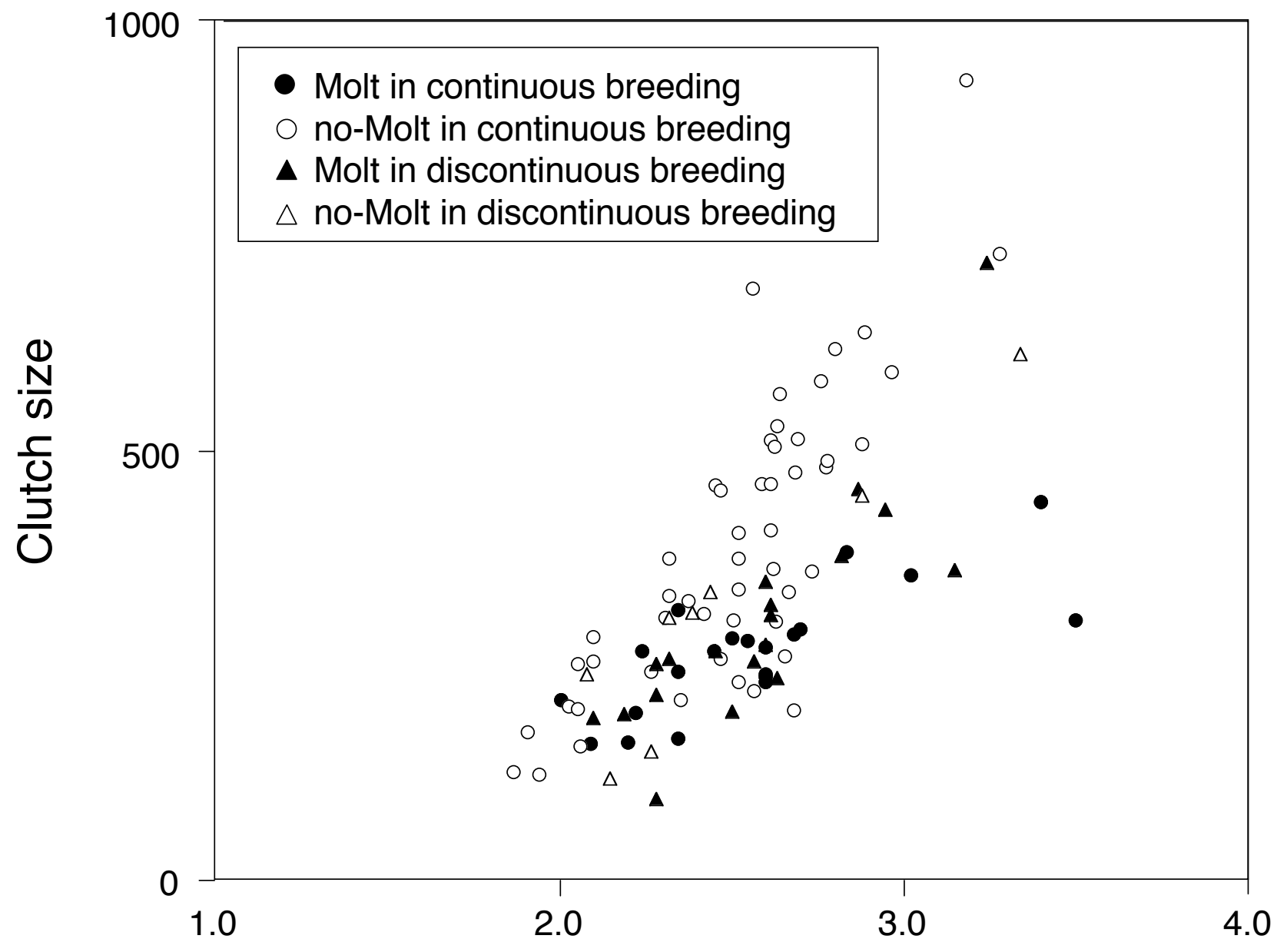

Female size (SL, mm)

Fig. 3 


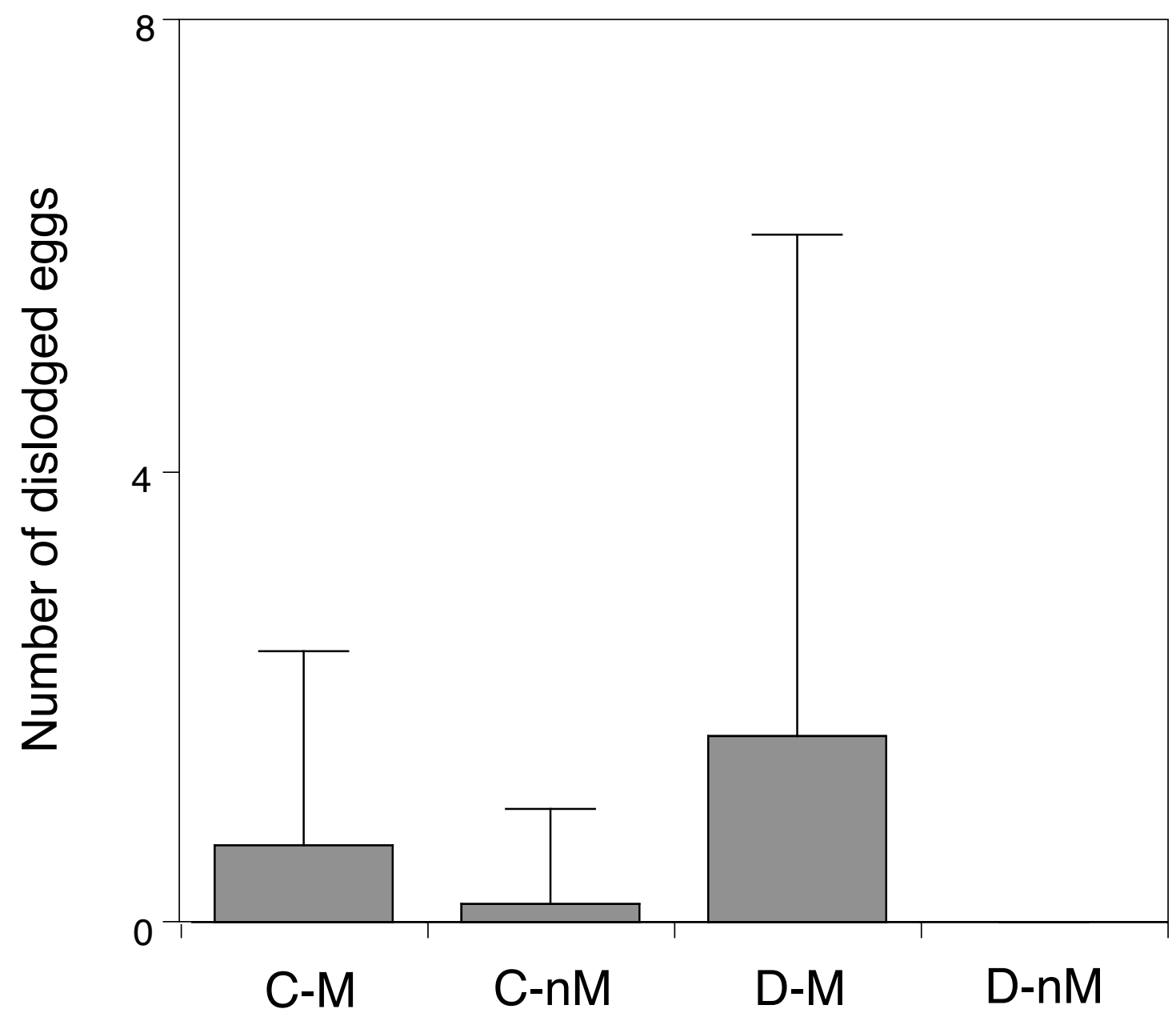

Fig. 4 


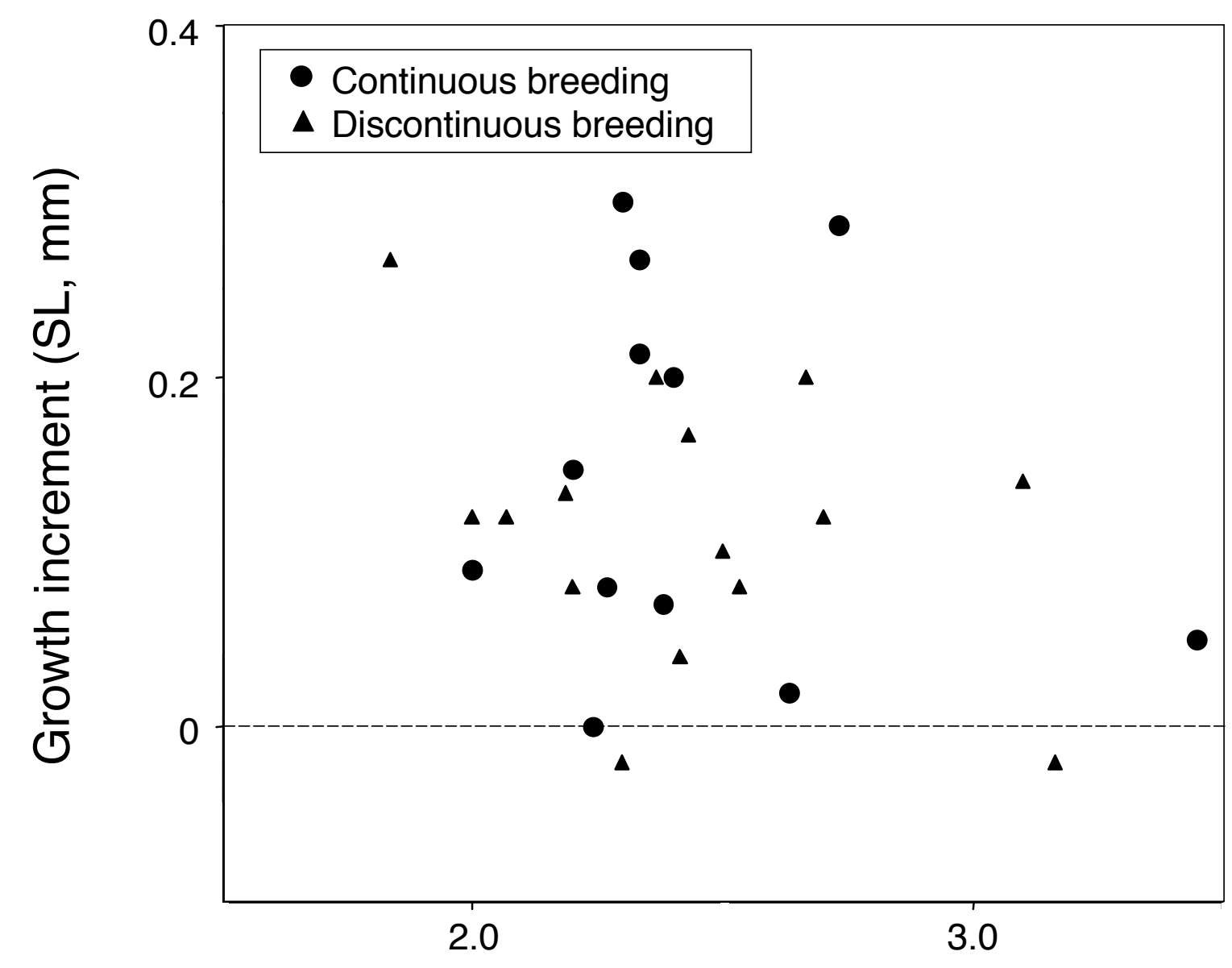

Female size (SL, mm)

Fig. 5 
Table 1. The number of molt/no-molt females in continuous/discontinuous breeding in populations of Pagurus hermit crabs. There were significant negative correlations between molt and continuity of breeding in all populations (Kendall's rank correlation test).

\begin{tabular}{|c|c|c|c|c|c|c|c|c|c|}
\hline \multirow[b]{2}{*}{ Species } & \multirow[b]{2}{*}{ Study site } & \multirow[b]{2}{*}{ Study period } & \multicolumn{2}{|c|}{ Continuous breeding } & \multicolumn{2}{|c|}{ Discontinuous breeding } & \multirow[b]{2}{*}{ Total } & \multirow[b]{2}{*}{$\tau$} & \multirow[b]{2}{*}{$\mathrm{p}$} \\
\hline & & & molt & no-molt & molt & no-molt & & & \\
\hline P. filholi & Usa, Tosa Bay & Jan. 2003 - Feb. 2003 & 19 & 55 & 15 & 2 & 91 & -0.504 & $<0.001$ \\
\hline P. filholi & Usa, Tosa Bay & Jan. 2004 - Feb. 2004 & 16 & 59 & 31 & 7 & 113 & -0.577 & $<0.001$ \\
\hline P. filholi & Hane, Tosa Bay & Jan. 2004 - Feb. 2004 & 10 & 22 & 21 & 7 & 60 & -0.437 & $<0.001$ \\
\hline P. filholi & Kattoshi, Hakodate Bay & May 2005 - Jun. 2005 & 19 & 83 & 104 & 71 & 277 & -0.396 & $<0.001$ \\
\hline P. filholi & Kattoshi, Hakodate Bay & May 2006 - Jun. 2006 & 43 & 78 & 76 & 48 & 245 & -0.258 & $<0.001$ \\
\hline P. minutus & Usa, Tosa Bay & Jan. 2003 - Feb. 2003 & 47 & 65 & 39 & 10 & 161 & -0.347 & $<0.001$ \\
\hline P. minutus & Usa, Tosa Bay & Jan. 2004 - Feb. 2004 & 22 & 54 & 20 & 8 & 104 & -0.384 & $<0.001$ \\
\hline P. nigrivittatus & Hane, Tosa Bay & Jan. 2004 - Feb. 2004 & 23 & 24 & 110 & 71 & 228 & -0.097 & 0.029 \\
\hline P. lanuginosus & Kattoshi, Hakodate Bay & Apr. 2006 - May 2006 & 0 & 9 & 10 & 42 & 61 & -0.184 & 0.036 \\
\hline
\end{tabular}


Table 2. Summary of effects from logistic regression on the prenuptial molt for female size, shell size and reproductive parameters in Pagurus minutus. Since both clutch size and shell size highly correlated with female size, we calculated their residuals from the least squares regressions between each variable and female size, and used the residuals as variables in the logistic regression analysis.

\begin{tabular}{lrrrr}
\hline Variable & Coef. & SE & \multicolumn{1}{c}{$z$} & \multicolumn{1}{c}{$\mathrm{p}$} \\
\hline Intercept & 4.768 & 2.308 & 2.066 & 0.039 \\
Female size & -1.726 & 0.917 & -1.882 & 0.060 \\
Shell size (adjusted for female size) & 0.383 & 0.198 & 1.935 & 0.053 \\
Clutch size (adjusted for female size) & -0.013 & 0.004 & -3.411 & $<0.001$ \\
Number of dislodged eggs & 0.553 & 0.279 & 1.979 & 0.048 \\
Continuous/Discontinuous & -1.745 & 0.587 & -2.972 & 0.003 \\
\hline
\end{tabular}

